\title{
Assessment of Crop Water Footprint for Different Varieties of Groundnut (Arachis hypogaea)
}

\author{
J. Ramachandran, R. Lalitha ${ }^{1}$, S. Vallal Kannan², K. Sivasubramanian ${ }^{3}$
}

10.18805/IJARe.A-5831

\begin{abstract}
Background: Water Footprint is a recently used indicator which helps to reduce water depletion and alleviate water stress in areas of drought and proper crop cultivation. Hence a study was taken up to assess the crop water footprint of different groundnut varieties namely TMV 7, VRI 2, VRI 3, VRI Gn 5, VRI Gn 6, CO 3, CO Gn 4, ALR 3 and TMV Gn 13 cultivated during Kharif and Rabi seasons at Tiruchirapalli district of Tamil Nadu.

Methods: The total water requirement, blue and green crop evapotranspiration, blue and green crop water use and total water footprint for different varieties of groundnut were estimated using CROPWAT 8.0 Windows. A comparison was made between the water footprint of groundnut varieties and the strategies to reduce water footprint is presented.

Result: The total water footprint for groundnut varieties ranged from 2603 to $4889 \mathrm{~m}^{3}$ ton $^{-1}$ (CV of $26 \%$ ) during kharif season, while it was ranged from 1465 to $2470 \mathrm{~m}^{3}$ ton $^{-1}$ (CV of $18 \%$ ) during rabi season. It was found that in all groundnut varieties the blue water footprint is higher than the green water footprint, while VRI Gn 5 variety had minimum total water footprint. It was concluded that, the groundnut production is affected by different levels of blue water stress which requires effective irrigation practices and water management strategies to enhance the crop production.
\end{abstract}

Key words: Blue and green water footprint, Crop evapotranspiration, Groundnut.

\section{INTRODUCTION}

Groundnut, also commonly known as Peanut (Arachis hypogaea), is a tropical legume mainly grown to produce oil and for human and animal consumption (Rami et al., 2013). Groundnut is the major oilseed and single largest source of edible oils in India. India is the second largest producer of groundnuts after China (Shruthi et al., 2017). Gujarat is the largest producer contributing 25 per cent of the total production of groundnut followed by Andhra Pradesh, Tamil Nadu and Karnataka (Sameer et al., 2014). Groundnut accounts for about 50 per cent of area and 45 per cent of oil production among the soil seed crop in India. In Tamil Nadu, Groundnut is grown in an area of 3.355 Lakh Hectare with normal production of 9.112 Lakh Metric Tonne and productivity of $2,716 \mathrm{~kg} / \mathrm{ha}$. It can be sold as shelled or unshelled to generate income, thereby improving the farmer's income (Murray and Kostadini, 2016). Groundnuts have large water footprints per unit of mass and protein (Mekonnen and Hoekstra, 2011) and contribute already today in different parts of the world to blue water stress (Fulton et al., 2019; Vanham et al., 2020). Groundnut is relatively drought tolerant crop but pod yield reduction is very high if proper soil moisture during critical growth stages like flowering and pod formation (Baskaran et al., 2020). The amount of water used by the crop is determined by the potential evapotranspiration during the crop period and the degree of soil cover (Allen et al., 1998). The water requirement varies with soil type and agro-climates. Currently information about a commodity's individual water consumption is essential, which is called as water footprint
${ }^{1}$ Department of Soil and Water Conservation Engineering Agricultural Engineering College and Research Institute, Tamil Nadu Agricultural University, Kumulur-621 712, Trichy, Tamil Nadu, India. ${ }^{2}$ Department of Irrigation and Drainage Engineering, Agricultural Engineering College and Research Institute, Tamil Nadu Agricultural University, Kumulur-621 712, Trichy, Tamil Nadu, India.

${ }^{3}$ Office of Controller of Examination, Tamil Nadu Agricultural University, Coimbatore-641 003, Tamil Nadu, India.

Corresponding Author: J. Ramachandran, Department of Agricultural Engineering, Agricultural College and Research Institute, Tamil Nadu Agricultural University, Madurai-625 104, Tamil Nadu, India. Email: eeesurya.tnau@gmail.com

How to cite this article: Ramachandran, J., Lalitha, R., Kannan, S.V. and Sivasubramanian, K. (2021). Assessment of Crop Water Footprint for Different Varieties of Groundnut (Arachis hypogaea). Indian Journal of Agricultural Research. DOI:10.18805/IJARe.A5831.

Submitted: 27-05-2021 Accepted: 17-08-2021 Online:

of that commodity. Water footprint is defined as the total volume of freshwater that is used to produce the product (Hoekstra and Hung, 2002). The freshwater used can be further differentiated as green, blue or grey. Green refers to rainwater, blue is the surface and groundwater used for irrigation, and grey is the freshwater used to disperse fertilizer and pesticides. Crop production requires both blue and green water resources (Mekonnen and Hoekstra, 2011). The productivity of food crops like paddy, groundnut and pulses can be increased to the target levels by proper water 
management practices. Measurement of water footprint is important because it establishes a basis for understanding how much of water, the individual commodities consume (Hoekstra and Hung, 2002). Increased demand for food crops has meant that countries are relying more on underground aquifers in the absence of rain. Since the world's freshwater supplies are depleting, it is critical to know the water footprint in order to study, measure, and implement more efficient practices in agricultural sector. Veettil and Mishra (2016) indicated that due to changing pattern in climate variable and sectorial water demands, studies related to variability of water footprint is desirable for formulating water management practices. Zhao et al. (2016) investigated the variations of blue and green water resources under different land use change, agricultural irrigation expansion and climate variability scenarios. Mali et al. (2015) assessed blue and green components of evapotranspiration of 15 major crops grown in agricultural production units of Gomati basin by using CROPWAT model. It was reported that the blue water use by rabi crops was considerably higher than that of kharif crops. Adarsh et al. (2019) mentioned that the specific role of pulses in cropping system includes low water footprint and provides economic profitability to farmers.

Hence identification of water footprint of crops and cropping pattern is the need of the hour to find out the best crop for a region, particularly to avoid water stress in that region and also helps in switching over to less water intensive crop. The aim of this study was to estimate the total water footprint using the FAO CROPWAT model 8.0 Windows for different groundnut varieties namely TMV 7, VRI 2, VRI 3, VRI Gn 5, VRI Gn 6, CO 3, CO Gn 4, ALR 3 and TMV Gn 13, as it is required for studying the irrigation water management strategies to get maximum production.

\section{MATERIALS AND METHODS Study area}

The water footprint of groundnut varieties cultivated in Tiruchirapalli District of Tamil Nadu, India was estimated in this study. Tiruchirappalli District is a centrally located district in Tamil Nadu State, has an area of $4403.83 \mathrm{~km}^{2}$. The topography of Tiruchirappalli District is almost plain except for the short range of Pachaimalai hills in the North. Tiruchirapalli district is located between $10^{\circ} 00^{\prime} \mathrm{N}$ and $11^{\circ} 30^{\prime} \mathrm{N}$ and $77^{\circ} 45^{\prime} \mathrm{E}$ and $78^{\circ} 50^{\prime} \mathrm{E}$ and $78 \mathrm{~m}$ above mean sea level. Tiruchirappalli district is agriculturally rich due to the availability of fertile lands and presence of perennial rivers. Agriculture is the main occupation of major population in the study area. Agriculture sector provides the major source of income to the population and the major crops are paddy, banana, sugarcane, cotton, groundnut, maize etc. Oilseeds are also one of the major crops cultivated in the study area. It includes groundnut (6232 ha), gingely (1567 ha), castor ( $255 \mathrm{ha}$ ) and sunflower ( $85 \mathrm{ha}$ ) crops. Fig 1 shows the district area coverage of oilseeds in which groundnut is the major oil seed crop cultivated in the study area. TMV and VRI are the promising varieties of groundnut cultivated. It is sown during the month of June-July (Anippattam) (Kharif season) and December-January (Margazhipattam) (Rabi season). TMV 7, VRI 2, VRI Gn 5, VRI Gn 6, TMV Gn 13 are the varieties sown during June-July. TMV 7, CO 3, CO Gn 4, VRI 2, VRI 3, ALR 3, VRI Gn 5, VRI Gn 6, TMV Gn 13 are the varieties sown during December-January. A detailed description of the varieties via duration (days), average yield of pods under rainfed and irrigated condition ( $\mathrm{kg} / \mathrm{ha}$ ), shelling percentage and oil content percentage is given in Table 1 and 2 .

\section{Estimation of crop water requirement using CROPWAT 8.0}

CROPWAT 8.0 was used to estimate the crop water requirement. Firstly, monthly reference evapotranspiration was estimated by Penman Monteith equation (Allen et al., 1998) in CROPWAT 8.0 window from the meteorological data collected from the observatory. The equation for estimating the daily grass-reference evapotranspiration is given as follows:

$$
\mathrm{ET}_{0}=\frac{0.408^{*} \Delta\left(\mathrm{R}_{\mathrm{n}}-\mathrm{G}\right) \Delta+\gamma \frac{900}{[\mathrm{~T}+273]}{ }^{*} u^{*}\left(\mathrm{e}_{\mathrm{a}}-\mathrm{e}_{\mathrm{d}}\right)}{\Delta+\gamma(1+0.34 * u)}
$$

Where;

$\mathrm{ET}_{0}=$ reference evapotranspiration $\left[\mathrm{mm} \mathrm{day}^{-1}\right], \mathrm{R}_{\mathrm{n}}=$ net radiation at the crop surface [ $\mathrm{MJ} \mathrm{m}^{-2}$ day $^{-1}$ ], $\mathrm{G}=$ soil heat flux density [MJ m$~^{-2}$ day $^{-1}$ ], $\mathrm{T}=$ mean daily air temperature $\left[{ }^{\circ} \mathrm{C}\right], \mathrm{u}$ = wind speed at $2 \mathrm{~m}$ height $\left[\mathrm{m} \mathrm{s}^{-1}\right], \mathrm{e}_{\mathrm{s}}=$ saturation vapour pressure $[\mathrm{kPa}], \mathrm{e}_{\mathrm{a}}=$ actual vapour pressure $[\mathrm{kPa}], \mathrm{e}_{\mathrm{s}}-\mathrm{e}_{\mathrm{a}}=$ saturation vapour pressure deficit [kPa], $\Delta=$ slope of vapour pressure curve $\left[\mathrm{kPa}^{\circ} \mathrm{C}^{-1}\right], \gamma=$ psychrometric constant $\left[\mathrm{kPa}^{\circ} \mathrm{C}^{-1}\right]$.

The full dataset for 22 years (1995-2017) collected from the meteorological observatory located at Agricultural Engineering College and Research Institute, Kumulur, Lalgudi Taluk, Trichy were used in estimating reference evapotranspiration.

The effective rainfall $\left(P_{\text {eff }}\right)$ was calculated by using Soil Conservation Service method of the United States Department of Agriculture (USDA SCS) as it is one of the most widely used methods. The rainfall data for 22 years (1995-2017) was also collected from the meteorological observatory located at Agricultural Engineering College and Research Institute, Kumulur, Lalgudi Taluk, Trichy.

The crop evapotranspiration (ET $\mathrm{C}_{\mathrm{c}}$ ) under optimal conditions was estimated which is equal to crop water requirement (CWR). Optimal means disease-free, wellfertilized crops, grown in large fields, under optimum soil water conditions and achieving full production under the given climatic conditions. ET was estimated at a ten day time step throughout the total growing season as mentioned by Michael (1978) as follows:

Where;

$$
\mathrm{ET}_{\mathrm{C}}=\mathrm{ET}_{0} \mathrm{~K}_{\mathrm{C}}
$$

$\mathrm{ET}_{\mathrm{o}}=$ represents the reference evapotranspiration and $\mathrm{K}_{\mathrm{c}}=$ refers to the crop coefficient. The crop coefficient is calculated by two methods as explained below. 


\section{FA056 Tabulated $\mathrm{K}_{\mathrm{c}}$}

Crop coefficients are used to estimate the crop water requirement. Generally, the value of crop coefficient is taken from the FAO Crop Evapotranspiration guidelines (Allen et al., 1998) for different crops at different stages and the crop water requirement is calculated. The value of $K_{c}$ for groundnut was taken from the tabulated $\mathrm{K}_{\mathrm{c}}$ values given in the FAO Crop Evapotranspiration guidelines (Allen et al., 1998) for different crops at different stages.

\section{Estimation of blue and green water evapotranspiration}

Subsequently the green water evapotranspiration ( $\left.E T_{\text {green }}\right)$ was calculated as the minimum of total crop evapotranspiration $\left(E T_{c}\right)$ and effective rainfall $\left(P_{\text {eff }}\right)$, with a ten day time step. The total green water evapotranspiration is obtained by summing up $\mathrm{ET}_{\text {green }}$ over the growing period (Hoekstra et al., 2011).

$$
\mathrm{ET}_{\text {green }}=\min \left(E T_{c}, \mathrm{P}_{\text {eff }}\right)
$$

The blue water evapotranspiration $\left(\mathrm{ET}_{\text {blue }}\right.$ ) is estimated as the difference between the total crop evapotranspiration $\left(E T_{c}\right)$ and the total effective rainfall $\left(P_{\text {eff }}\right)$ on a daily basis (Hoekstra et al., 2011).

$$
\mathrm{ET}_{\text {blue }}=\max \left(0, \mathrm{ET}_{\mathrm{c}}-\mathrm{P}_{\text {eff }}\right)
$$

When the effective rainfall is greater than the crop total crop evapotranspiration, $\mathrm{ET}_{\text {blue }}$ is equal to zero. The total blue water evapotranspiration is obtained by adding $\mathrm{ET}_{\text {blue }}$ over the whole growing period (Hoekstra et al., 2011).

\section{Estimation of crop water footprint}

The water footprint of a product is defined as the total volume of fresh water that is used directly or indirectly to produce the product. The estimated crop evapotranspiration in $\mathrm{mm}$ is converted to $\mathrm{m}^{3} \mathrm{ha}^{-1}$ by applying a factor 10 which is called as crop water use (Hoekstra et al., 2011).

$$
\begin{aligned}
& \mathrm{CWU}_{\text {green }}=10 * \mathrm{ET}_{\text {green }} \\
& \mathrm{CWU}_{\text {blue }}=10 * \mathrm{ET}_{\text {blue }}
\end{aligned}
$$

The green component in the process water footprint of a crop $\left(\mathrm{WF}_{\text {proc,green, }} \mathrm{m}^{3}\right.$ ton $\left.^{-1}\right)$ was calculated as the green component in crop water use $\left(\mathrm{CWU} \mathrm{U}_{\text {green }}, \mathrm{m}^{3} \mathrm{ha}^{-1}\right)$ divided by the crop yield $Y$ (ton ha-1). The blue component of water footprint $\left(W F_{\text {proc,blue }}, m^{3}\right.$ ton $\left.^{-1}\right)$ was also calculated from blue component in crop water use $\left(\mathrm{CWU}_{\text {green }}, \mathrm{m}^{3} \mathrm{ha}^{-1}\right)$ in the similar way. The equations used are listed below (Hoekstra et al., 2011):

$$
\mathrm{WF}_{\text {proc, green }}=\frac{\mathrm{CWU}_{\text {green }}}{\mathrm{Y}}
$$

The yield under rainfed and irrigated conditions for different varieties is shown in Table 1 and 2, respectively. Thus the crop water footprint for groundnut varieties is estimated by the above methodology.

$$
\mathrm{WF}_{\text {proc }, \text { blue }}=\frac{\mathrm{CWU}_{\text {blue }}}{\mathrm{Y}}
$$

\section{RESULTS AND DISCUSSION Crop coefficient $\left(K_{c}\right)$ for groundnut}

The value of $\mathrm{K}_{\mathrm{c}}$ for groundnut was 0.40 during the initial stage, 1.50 during the middle stage and 0.60 during the end stage. The crop coefficient curve for groundnut is given in the Fig 2. According to Allen et al. (1998), it varies with plant development stage, beginning with small values during establishment, reaching a maximum value in full-developed plants and, then decreasing at the end of vegetative cycle and early maturation. The results were in agreement with results obtained by Ramachandran et al. (2021) who suggested that, $\mathrm{K}_{\mathrm{c}}$ values are useful in determining crop water requirement and efficient irrigation schedules.

\section{Crop water footprint for groundnut during Kharifseason}

Table 3 presents the crop water footprint during Kharif season. Based on the assessment, the total water requirement for groundnut varieties ranged from 538 to 602 $\mathrm{mm}$ with mean of $554 \mathrm{~mm}$ (CV of 5\%). VRI Gn 6 had the maximum water requirement $(602 \mathrm{~mm})$ compared to the other varieties. The total water footprint for groundnut varieties ranged from 2603 to $4889 \mathrm{~m}^{3}$ ton $^{-1}$ with mean of $3395 \mathrm{~m}^{3}$ ton $^{-1}$ (CV of $26 \%$ ). TMV 7 had maximum total water footprint (4889 $\mathrm{m}^{3}$ ton $\left.^{-1}\right)$ and VRI Gn 5 had minimum total water footprint $\left(2603 \mathrm{~m}^{3}\right.$ ton $\left.^{-1}\right)$. The average yield of pods $(2133 \mathrm{~kg} / \mathrm{ha})$ and percentage of oil content (51\%) was also high in VRI Gn 5. The green and blue water footprint for different groundnut varieties is shown in Fig 3 . It was found that for all varieties the blue water footprint is higher than the green water footprint. The average green water footprint was $1404 \mathrm{~m}^{3}$ ton $^{-1}$ and blue water footprint was $1990 \mathrm{~m}^{3}$ ton $^{-1}$ during kharif season. Due to vagaries of monsoon, kharif groundnut shows great unstability in production and productivity. The timing and duration of moisture stress is responsible for reduction in yield. By following practices like incorporation of decomposed coconut coirpith in soil, soil mulches, broad bed and furrow system of planting and also beds covered with polyethylene film mulches can be effective water management in kharif Groundnut.

\section{Crop water footprint for groundnut during Rabi season}

Table 4 presents the crop water footprint during rabi season.

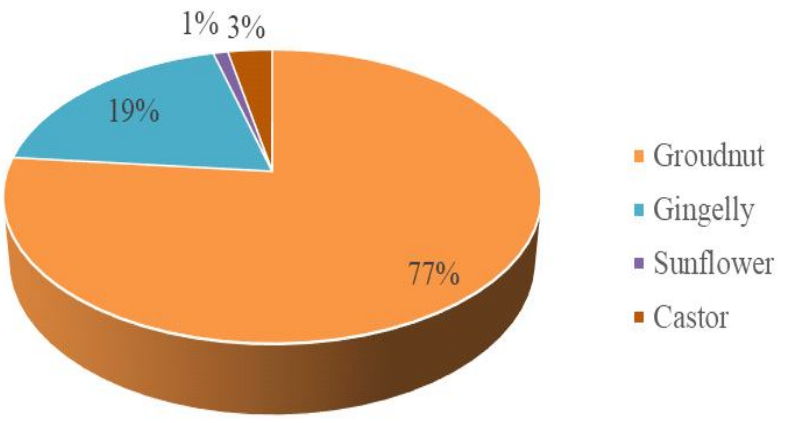

Fig 1: Oil seeds area coverage in the study area. (Source: Tamil Nadu Rural Transformation Project Report, 2018-19). 
Table 1: Description of groundnut varieties grown during Kharif season (June-July).

\begin{tabular}{lccccc}
\hline Particulars & TMV 7 & TMV Gn 13 & VRI 2 & VRI Gn 5 & VRI Gn 6 \\
\hline Duration (days) & $100-105$ & $100-105$ & $100-105$ & $105-110$ & $120-125$ \\
Average yield of pods & 1100 & 1613 & 1790 & 2133 & 1916 \\
under rainfed (kg/ha) & & & 74.8 & 75.0 & 75.0 \\
Shelling \% & 74.0 & 71.4 & 48.0 & 51.0 & 50.0 \\
Oil content \% & 49.6 & 50.0 & &
\end{tabular}

Source: https://agritech.tnau.ac.in/agriculture/oilseeds_groundnut.html.

Table 2: Description of groundnut varieties grown during Rabi season (December-January).

\begin{tabular}{|c|c|c|c|c|c|c|c|c|c|}
\hline Particulars & TMV 7 & TMV Gn 13 & VRI 2 & VRI 3 & VRI Gn 5 & VRI Gn 6 & $\mathrm{CO} 3$ & CO Gn 4 & ALR 3 \\
\hline Duration (days) & $100-105$ & $100-105$ & $100-105$ & 90 & $105-110$ & $120-125$ & $115-120$ & $115-120$ & $110-115$ \\
\hline $\begin{array}{l}\text { Average yield of pods } \\
\text { under Irrigated }(\mathrm{kg} / \mathrm{ha})\end{array}$ & 1900 & 2580 & 2060 & 1830 & 2384 & 2403 & 2150 & 1950 & 2720 \\
\hline Shelling \% & 74.0 & 71.4 & 74.8 & 73.0 & 75.0 & 75.0 & 70.0 & 70.0 & 69.0 \\
\hline Oil content $\%$ & 49.6 & 50.0 & 48.0 & 48.0 & 51.0 & 50.0 & 49.2 & 52.7 & 50.0 \\
\hline
\end{tabular}

Source: https://agritech.tnau.ac.in/agriculture/oilseeds_groundnut.html.

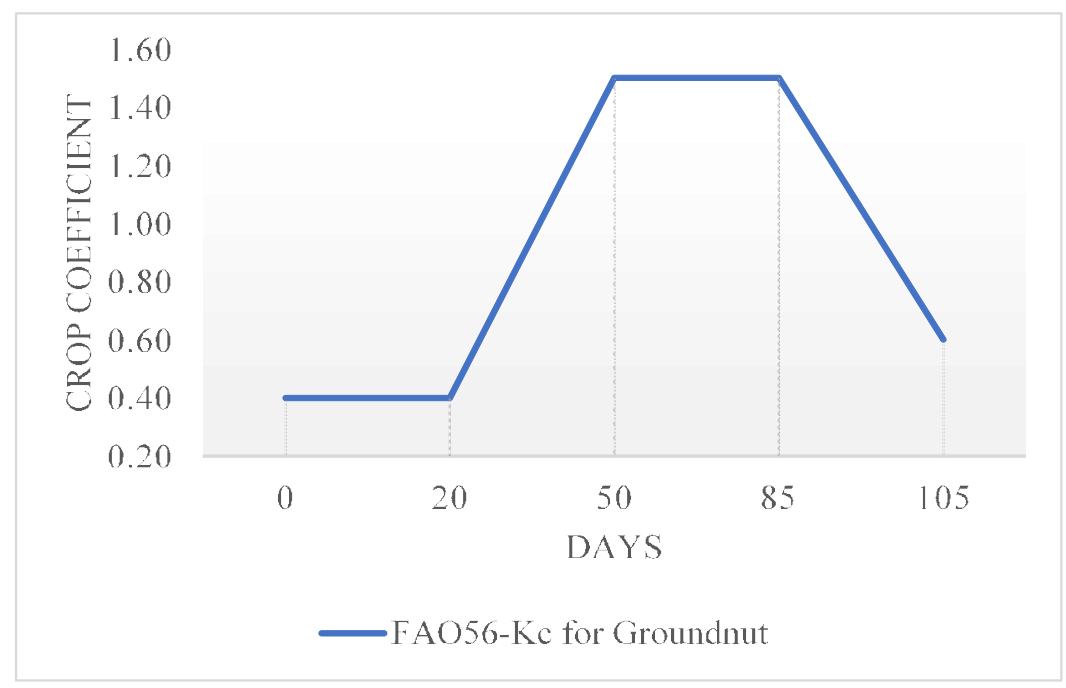

Fig 2: Variation of crop coefficient for groundnut at different stages.

Table 3: Crop water footprint for groundnut varieties grown during Kharif season.

\begin{tabular}{|c|c|c|c|c|c|c|c|c|}
\hline Varieties & $\begin{array}{l}\text { Total water } \\
\text { requirement } \\
(\mathrm{mm})\end{array}$ & $\begin{array}{c}\mathrm{ET}_{\text {Green }} \\
(\mathrm{mm})\end{array}$ & $\begin{array}{l}E T_{\text {Blue }} \\
(\mathrm{mm})\end{array}$ & $\begin{array}{l}\mathrm{CWU}_{\text {Green }} \\
\left(\mathrm{m}^{3} \mathrm{ha}^{-1}\right)\end{array}$ & $\begin{array}{l}\text { CWU } \\
\text { Blue } \\
\left(m^{3} h^{-1}\right)\end{array}$ & $\begin{array}{c}W F_{\text {Green }} \\
\left(m^{3} \text { ton }^{-1}\right)\end{array}$ & $\begin{array}{c}W F_{\text {Blue }} \\
\left(m^{3} \text { ton }^{-1}\right)\end{array}$ & $\begin{array}{r}\text { Total water } \\
\text { footprint } \\
\left(\mathrm{m}^{3} \text { ton }^{-1}\right)\end{array}$ \\
\hline TMV 7 & 538 & 215 & 323 & 2145 & 3233 & 1950 & 2939 & 4889 \\
\hline TMV Gn 13 & 538 & 215 & 323 & 2145 & 3233 & 1330 & 2004 & 3334 \\
\hline VRI 2 & 538 & 215 & 323 & 2145 & 3233 & 1198 & 1806 & 3004 \\
\hline VRI Gn 5 & 555 & 230 & 325 & 2303 & 3250 & 1080 & 1524 & 2603 \\
\hline VRI Gn 6 & 602 & 281 & 322 & 2806 & 3217 & 1465 & 1679 & 3144 \\
\hline Minimum & 538 & 215 & 322 & 2145 & 3217 & 1080 & 1524 & 2603 \\
\hline Maximum & 602 & 281 & 325 & 2806 & 3250 & 1950 & 2939 & 4889 \\
\hline Mean & 554 & 231 & 323 & 2309 & 3233 & 1404 & 1990 & 3395 \\
\hline SD & 28 & 29 & 1 & 286 & 12 & 337 & 559 & 877 \\
\hline CV (\%) & 5 & 12 & 0 & 12 & 0 & 24 & 28 & 26 \\
\hline
\end{tabular}

SD: Standard Deviation; CV: Coefficient of Variation. 
Based on the assessment, the total water requirement for groundnut varieties ranged from 331 to $482 \mathrm{~mm}$ with mean of $421 \mathrm{~mm}$ (CV of 12\%). Due to the seasonal changes, the total water requirement of groundnut in rabi season is less than kharif season. VRI Gn 6, CO 3 and CO Gn 4 had the maximum water requirement $(482 \mathrm{~mm})$ compared to the other varieties. The total water footprint for groundnut varieties ranged from 1465 to $2470 \mathrm{~m}^{3}$ ton $^{-1}$ with mean of $1892 \mathrm{~m}^{3}$ ton $^{-1}$ (CV of $18 \%$ ). Co Gn 4 had maximum total water footprint $\left(2470 \mathrm{~m}^{3}\right.$ ton $\left.^{-1}\right)$ and VRI Gn 5 had minimum total water footprint $\left(1465 \mathrm{~m}^{3}\right.$ ton $\left.^{-1}\right)$. It is noted that in both seasons VRI Gn 5 had minimum total water footprint.

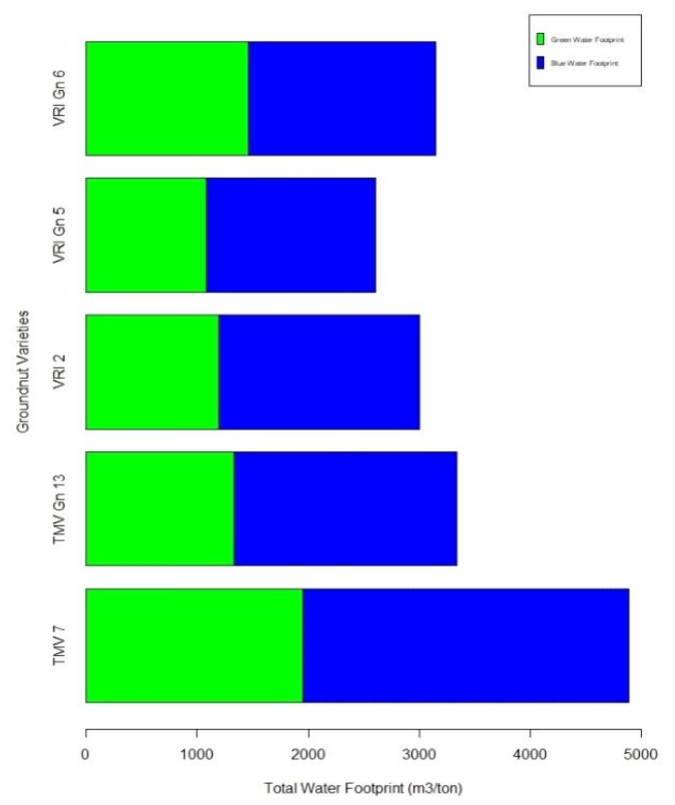

Fig 3: Total crop water footprint for groundnut varieties during Kharif season.
Moreover, water footprint of VRI Gn 5 is less during the rabi season $\left(1465 \mathrm{~m}^{3}\right.$ ton $\left.^{-1}\right)$ than kharif season $\left(2603 \mathrm{~m}^{3}\right.$ ton $\left.^{-1}\right)$. Though the highest average yield of pods was seen in ALR $3(2720 \mathrm{~kg} / \mathrm{ha})$ variety, the water footprint was less in VRI Gn 5 variety with an average yield of pods (2384 kg/ha) and percentage of oil content (51\%). The green and blue water footprint for different groundnut varieties during rabi season is shown in Fig 4. It was found that for all varieties the blue water footprint is higher than the green water footprint. The average green and blue water footprint were $206 \mathrm{~m}^{3}$ ton $^{-1}$ and $1686 \mathrm{~m}^{3}$ ton $^{-1}$ respectively during kharif season, while it was reduced in rabi season.

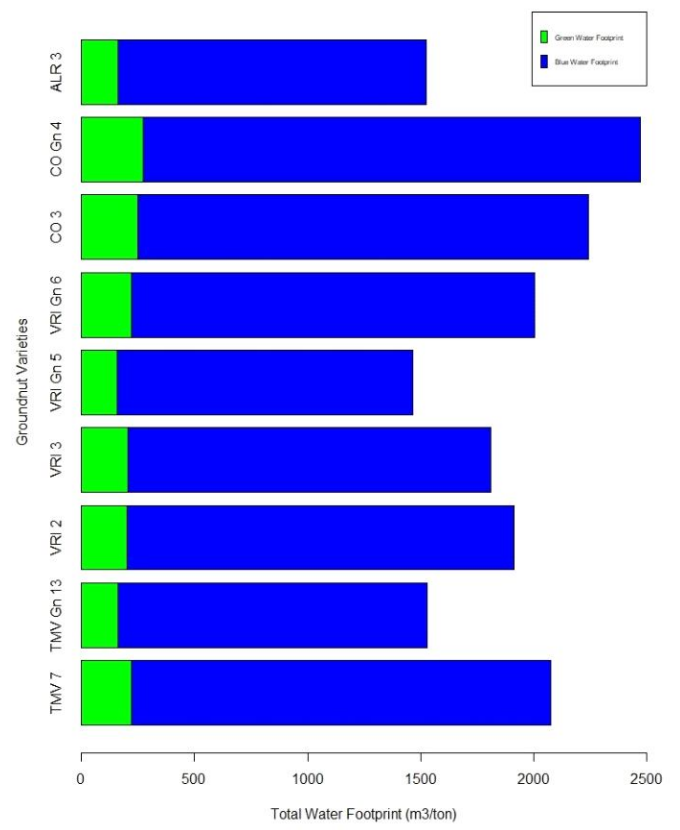

Fig 4: Total crop water footprint for groundnut varieties during Rabi season.

Table 4 Crop Water Footprint for Groundnut Varieties grown during Rabi season.

\begin{tabular}{|c|c|c|c|c|c|c|c|c|}
\hline Varieties & $\begin{array}{l}\text { Total water } \\
\text { requirement } \\
(\mathrm{mm})\end{array}$ & $\begin{array}{l}\mathrm{ET}_{\text {Green }} \\
(\mathrm{mm})\end{array}$ & $\begin{array}{l}\mathrm{ET}_{\text {Blue }} \\
(\mathrm{mm})\end{array}$ & $\begin{array}{l}\mathrm{CWU} \text { Green } \\
\left(\mathrm{m}^{3} \mathrm{ha}^{-1}\right)\end{array}$ & $\begin{array}{l}\mathrm{CWU}_{\text {Blue }} \\
\left(\mathrm{m}^{3} \mathrm{ha}^{-1}\right)\end{array}$ & $\begin{array}{c}W F_{\text {Green }} \\
\left(m^{3} \text { ton }^{-1}\right)\end{array}$ & $\begin{array}{c}\mathrm{WF}_{\text {Blue }} \\
\left(\mathrm{m}^{3} \text { ton }^{-1}\right)\end{array}$ & $\begin{array}{c}\text { Total water } \\
\text { footprint } \\
\left(\mathrm{m}^{3} \text { ton }^{-1}\right)\end{array}$ \\
\hline TMV 7 & 394 & 42 & 352 & 419 & 3522 & 221 & 1854 & 2074 \\
\hline TMV Gn 13 & 394 & 42 & 352 & 419 & 3522 & 162 & 1365 & 1528 \\
\hline VRI 2 & 394 & 42 & 352 & 419 & 3522 & 203 & 1710 & 1913 \\
\hline VRI 3 & 331 & 38 & 294 & 376 & 2938 & 205 & 1605 & 1811 \\
\hline VRI Gn 5 & 415 & 44 & 371 & 443 & 3708 & 156 & 1308 & 1465 \\
\hline VRI Gn 6 & 482 & 53 & 428 & 533 & 4284 & 222 & 1783 & 2005 \\
\hline CO 3 & 482 & 53 & 428 & 533 & 4284 & 248 & 1993 & 2240 \\
\hline CO Gn 4 & 482 & 53 & 428 & 533 & 4284 & 273 & 2197 & 2470 \\
\hline ALR 3 & 415 & 44 & 371 & 443 & 3708 & 163 & 1363 & 1526 \\
\hline Minimum & 331 & 38 & 294 & 376 & 2938 & 156 & 1308 & 1465 \\
\hline Maximum & 482 & 53 & 428 & 533 & 4284 & 273 & 2197 & 2470 \\
\hline Mean & 421 & 46 & 375 & 458 & 3752 & 206 & 1686 & 1892 \\
\hline SD & 52 & 6 & 46 & 60 & 457 & 40 & 306 & 346 \\
\hline $\mathrm{CV}(\%)$ & 12 & 13 & 12 & 13 & 12 & 20 & 18 & 18 \\
\hline
\end{tabular}


The average blue water use by different varieties of groundnut was $3233 \mathrm{~m}^{3} \mathrm{ha}^{-1}$ during kharif season and 3752 $\mathrm{m}^{3}$ ha $^{-1}$ during rabi season. Mali et al. (2015) indicated that, the blue water use by rabi crops is higher than that of kharif crops. The results agreed with the results obtained by Vanham et al. (2020) who indicated that, current global nut production is affected by different levels of blue water stress, in many regions of the world. Hence effective irrigation practices should be adopted to reduce the blue water stress and enhancing the crop production.

\section{CONCLUSION}

The total water footprint for groundnut varieties ranged from 2603 to $4889 \mathrm{~m}^{3}$ ton $^{-1}$ (CV of 26\%) and 1465 to $2470 \mathrm{~m}^{3}$ ton $^{-1}$ (CV of $18 \%$ ) during kharif and rabi seasons, respectively. It was noted that in both seasons VRI Gn 5 variety had minimum total water footprint compared to other varieties. Blue water footprint is higher than the green water footprint. Hence the groundnut production is affected by different levels of blue water stress. In recent decades, water demand always exceeds rainfall and at the same time, exploitation of groundwater has increased greatly particularly for agricultural purpose. The only solution is judicious use of water by adopting modern water management techniques and thus the yield of crops can be boosted and full yield potential to be exploited.

\section{REFERENCES}

Adarsh, S., John, J. and Thomas, G. (2019). Role of Pulses in Cropping Systems: A Review. Agricultural Reviews. 40: 185-191.

Allen, R.G., Pereira, L.S., Raes, D. and Smith, M. (1998). Crop evapo-transpiration: Guidelines for computing crop water requirements. Rome: Food and Agricultural Organization.

Baskaran, R., Karunakaran, V. and Kamaraj, A. (2020). Effect of growing degree days on yield attributes and yield of groundnut. Current Journal of Applied Science and Technology. 39(22): 53-56.

Fulton, J., Norton, M. and Shilling, F. (2019). Water-indexed benefits and impacts of California almonds. Ecological Indicators. 96: 711-717.
Hoekstra, A.Y., and Hung, P.Q. (2002). Virtual Water Trade: A quantification of virtual water flows between nations in relation to international crop trade Value of Water Research Report (Vol. 11). The Netherlands.

Hoekstra, A.Y., Chapagain, A.K., Aldaya, M.M., Mekonnen, M.M. (2011). The water footprint assessment manual: setting the global standard. Earthscan Publications, Dunstan House, London, UK.

Mali, S.S., Singh, D.K., Sarangi, A., Khanna, M., Parihar, S.S., Das, D.K. (2015). Variability Mapping of Crop Evapotranspiration for Water Footprint assessment at Basin Level. Indian Journal of Soil Conservation. 43(1): 255-259.

Mekonnen, M.M. and Hoekstra, A.Y. (2011). The green, blue and grey water footprint of crops and derived crop products. Hydrol. Earth Syst. Sci. 15: 1577-1600.

Michael, A.M. (1978) Irrigation Efficiency Principles of Agricultural Engineering. Vol. 11, Jain Brothers, Jodhpur. 113-178.

Murray, M. and Kostadini G. (2016). Do improved groundnut seed make african farmers more food secure from Uganda. Journal of Agricultural and Applied Economics. 48(3): 219-240.

Ramachandran, J., Lalitha, R., Vallal Kannan, S. (2021). Estimation of site-specific crop coefficients for major crops of lalgudi block in Tamil Nadu using remote sensing based Algorithms. Journal of Agricultural Engineering. 58(1): 62-72.

Rami, J.-F., Leal-Bertioli, S., Foncéka, D., Moretzsohn, M., Bertioli, D. (2013). Groundnut. Alien Gene Transfer in Crop Plants. Springer Science, 2.

Sameer, L., Gurikar R., Kulkarni, G. N. (2014). Production and Export of Ground nut from India - An Overview. International Research Journal of Agricultural Economics and Statistics. 5: 293-298.

Shruthi, G., Rao, D., Devi, L. Masih, M. (2017). Analysis of Area, Production and Productivity of Groundnut Crop in Telangana. Agric. Sci. Digest. 37(2): 151-153

Vanham, D., Mekonnen, M., Hoekstra, A. (2020). Treenuts and groundnuts in the EAT-Lancet reference diet: Concerns regarding sustainable water use. Global Food Security. 24: $1-7$

Veettil, A.V. and Mishra, A.K. (2016). Water security assessment using blue and green water footprint concepts. Journal of Hydrology. 542: 589-602.

Zhao, A., Zhu, X., Liu, X., Pan, Y., Zuo, D. (2016). Impacts of land use change and climate variability on green and blue water resources in the Weihe River Basin of Northwest China. Catena. 137: 318-327. 